\title{
Mimosine As Well As Serum Starvation Can Be Used for Cell Cycle Synchronization of Sheep Granulosa Cells
}

\author{
Fatemeh Sadeghian-Nodoushan, ${ }^{1,2,3}$ Poopak Eftekhari-Yazdi, ${ }^{2}$ Azam Dalman,, \\ Hossein Eimani, ${ }^{2}$ and Houri Sepehri ${ }^{3}$ \\ ${ }^{1}$ Research and Clinical Center for Infertility, Shahid Sadoughi University of Medical Science, Yazd, Iran \\ ${ }^{2}$ Embryology Department, Royan Institute, Banihashem Square, Resalat Highway, P.O. Box 19395-4644, Tehran 16656 59911, Iran \\ ${ }^{3}$ Department of Biology, Faculty of Science, Tehran University, Tehran, Iran
}

Correspondence should be addressed to Poopak Eftekhari-Yazdi; eftekhari@royaninstitute.org

Received 29 July 2013; Accepted 13 September 2013; Published 2 January 2014

Academic Editors: Y. Jiang, Z. Liu, and J. Zhang

Copyright (C) 2014 Fatemeh Sadeghian-Nodoushan et al. This is an open access article distributed under the Creative Commons Attribution License, which permits unrestricted use, distribution, and reproduction in any medium, provided the original work is properly cited.

\begin{abstract}
This study was evaluated the effect of different synchronization protocols such as serum starvation for 1-3 days, confluency and chemical inhibitors on synchronization accuracy at G0/G1, apoptosis, and DNA synthesis in sheep granulosa cells. The cells were obtained from ovarian antral follicles of slaughtered sheep and used at first and fifth passages. Flow cytometry analysis showed that confluent cells, serum starvation for 24,48 , and 72 hours, and mimosine treatment significantly increased G0/G1 phase cells when compared to normally growing cells $(P<0.05)$. Nocodazole treatment increased the cell population in the G0/G1 stage when compared with the control group but did not change the G2/M stage population. Treatment of cells with mimosine, nocodazole, and serum starvation in three groups resulted in proliferation arrest $(P<0.05)$. Serum starvation for 72 hours significantly promoted apoptosis in granulosa cells $(P<0.05)$. The results of the primary culture and 5 th passage were the same. The use of 48 -hour serum starvation and mimosine treatments has been recommended because cell death in these groups was very similar to the control group.
\end{abstract}

\section{Introduction}

Recently, animal cloning by nuclear transfer (NT) has undergone rapid development. Somatic cell cloning has been successful in sheep [1], cattle [2], mice [3], goats [4], pigs [5], cats [6], rabbits [7], and horses [1]. Production of offspring by NT using somatic cells is possible, not only for the production of domestic animals $[8,9]$ but also for producing transgenic [10] or gene-targeted [11] offspring. However, somatic cell NT has a very low success rate, generally not more than $3 \%$, with a high frequency of fetal loss and an increase in prenatal mortality [12,13]. Many factors affect the efficiency of NT. One important factor is the cell cycle phase of the donor cells at NT [14]. Synchronization of the cell cycle stage of the recipient cytoplasm and the donor nucleus is essential for maintaining correct ploidy and for preventing DNA damage in NT reconstructed embryos. Previous studies have indicated that $\mathrm{S}$ phase nuclei transferred to MII oocytes undergo premature chromosome condensation (PCC) resulting in major chromatin aberrations and a reduction in development of NT embryos $[15,16]$. The cell cycle stage of the donor nucleus must be compatible with the high levels of maturation promoting factor (MPF) activity present in the metaphase II oocyte [17]. For this reason, only nuclei in the G1 [2, 18$20]$ or G0 phases $[3,21,22]$ of the cell cycle can be used for nuclear transplantation to enucleated MII oocytes. The use of nuclei at the G0/G1 phase improves nuclear reprogramming and the development of reconstituted embryos. Cells of higher passages are receptive to nuclear reprogramming. Additional support for this hypothesis came from a study by Enright et al. (2003) who have shown that cells of later passages contain less epigenetic modifications; that is, their histones are more acetylated than earlier passages [23]. Serum starvation $[24,25]$ and prolonged culture to confluency $[18$, 26] are commonly used methods to synchronize cells in 
the G0 or G0/G1 phase of the cell cycle, respectively. However, experiments differ in the duration of serum deprivation and concentration of serum. The efficiency of serum withdrawal in controlling the cell cycle and the effect of long-term starvation on the cell requires further investigation. Apart from these, several chemical compounds are effective in blocking the cells at various phases of the cell cycle [14]. For example, Prather et al. (1999) have reported that mimosine, a compound that synchronizes cell cycles in the G1 phase, could effectively increase the percentages of G1 cells [25]. The favorable effect of roscovitine on synchronization in the G0/G1 phase and subsequently on successful cattle NT has been reported [27]. However, adequate information on regulation of cell cycle stages in sheep donor cells is currently unavailable. Therefore, we investigated the effectiveness of three different cell cycle synchronization protocols in sheep granulosa cells and analyzed the effect of cell synchronization on cell apoptosis, DNA synthesis, and the cell cycle stage in both the primary culture and 5 th passage.

\section{Methods}

2.1. Cell Collection and Culture. Sheep ovaries were collected from slaughtered gilts and transported to the laboratory within 2 hours in a thermocontainer filled with phosphatebuffered saline (PBS; Gibco, Germany). Sheep ovaries were washed in PBS containing antibiotics (penicillin G $250 \mathrm{U} / \mathrm{mL}$ and streptomycin $250 \mu \mathrm{g} / \mathrm{mL}$ (Gibco, Germany) after being transferred to the laboratory. Granulosa cells were obtained by aspirating the ovarian follicles under a stereomicroscope into M199 medium (Sigma, USA) containing 25 mM HEPES, $15 \%$ fetal bovine serum (FBS; Gibco, Grand Island, NY), and $500 \mu \mathrm{g} / \mathrm{mL}$ heparin (Sigma). Then, cells were cultured in Dulbecco's modified Eagle's medium (DMEM; Gibco) supplemented with $10 \% \mathrm{FBS}$ in an atmosphere of $5 \% \mathrm{CO}_{2}$ and $95 \%$ air, at $37^{\circ} \mathrm{C}$. After two days of culture, the cells were checked for attachment (Figure 1(a)) and the medium was completely replaced.

When cells became confluent (Figure 1(b)), they were harvested by treatment with $0.25 \%$ Trypsin-EDTA (Gibco) at $37^{\circ} \mathrm{C}$ for two minutes. When the majority of cells detached and became round, the reaction was terminated by DMEM and the suspension was cultured. Cell culture was continued until the 5 th passage.

\subsection{Cell Cycle Synchronization and Experimental Designs.} Cells were cultured to near confluency in primary culture and the 5 th passage and divided into six experimental groups and one control group. Cells were cultured either in (i) DMEM + 10\% FBS until confluency (confluent inhibition group); (ii) DMEM $+10 \% \mathrm{FBS}+0.5 \mathrm{mM}$ mimosine for 24 hours (mimosine group); (iii-v) DMEM + 0.5\% FBS (serum starvation (SS) groups) for 24, 48, and 72 hours, and (vi) in DMEM $+10 \%$ FBS $+0.5 \mu \mathrm{g} / \mathrm{mL}$ nocodazole for 20 hours (nocodazole group). The control group consisted of normal growing cells that were allowed to grow to $70-80 \%$ confluency.
2.3. Flow Cytometry Analysis. Cells in each group were digested with $0.05 \%$ trypsin/EDTA and pipetted into suspension. Cell cycles were analyzed by FACS (BD FACS Calibur; BD Biosciences, San Jose, CA, USA) according to Boquest et al. In brief, the cell suspension (about $10^{6}$ cells $/ \mathrm{mL}$ ) was centrifuged for 10 minutes (116 g) and resuspended in $1 \mathrm{~mL}$ cold PBS; then, $3 \mathrm{~mL}$ of ice cold $70 \%$ ethanol was added slowly while vortexing. After ethanol fixation (20 minutes at $4^{\circ} \mathrm{C}$ ), cells were pelleted and then washed once with PBS that contained $5 \mathrm{mM}$ EDTA. Pelleted cells were stained by adding $1 \mathrm{~mL}$ PBS containing $30 \mu \mathrm{g} / \mathrm{mL}$ propidium iodide (PI) (Sigma) and $0.3 \mathrm{mg} / \mathrm{mL}$ RNaseA (Sigma) at room temperature for 1 hour [4]. Fluorescence data were obtained from 10,000 cells per sample. Stained cells were analyzed by flow cytometry and cell cycle analysis software (WinMDI version 2.9; Free Download Software Copyright, 1993-2000, Josef Trotter).

2.4. Detection of DNA Synthesis. DNA synthesis was assayed by 5-bromo2-deoxy-uridin (BrdU) incorporation (using an in situ detection kit (Roche Applied Science, Mannheim Germany). Cells were washed with PBS and cultured in DMEM containing $10 \mu \mathrm{M}$ BrdU for 24 hours at $37^{\circ} \mathrm{C}$. At the end of the culture, cells were washed with PBS and fixed by $70 \%$ ethanol glycine buffer $(50 \mathrm{mM}, \mathrm{pH} 2.0)$ at $-20^{\circ} \mathrm{C}$ for 30 minutes. The cells were then penetrated by $0.1 \%$ Triton X-100 for 10 minutes and blocked by $10 \%$ goat serum for 1 hour. After washing, $50 \mu \mathrm{L}$ anti-BrdU antibody (dilution 1:10) was added and cells were incubated overnight at $37^{\circ} \mathrm{C}$. The sample was washed in PBS and incubated with anti-mouse-Ig-fluorescein (dilution $1: 10$ ) for 1 hour at $37^{\circ} \mathrm{C}$ after which the sample was carefully washed in PBS and stained with $5 \mu \mathrm{L} / \mathrm{mL}$ PI for 5 minutes. Slides were mounted with glycerol and examined by the use of a fluorescence microscope. From each sample, at least 1000 nuclei were counted and data were represented as mean values for three independent experiments.

2.5. In Situ Detection of Cell Apoptosis. The effect of treatment on cell apoptosis was determined using a cell apoptosis detection kit (Roche Applied Science, Mannheim, Germany). Cells were fixed in $4 \%$ para-formaldehyde in PBS for 1 hour at room temperature, rinsed three times with PBS, and incubated with $0.3 \% \mathrm{H}_{2} \mathrm{O}_{2}$ in methanol for 1 hour to quench endogenous peroxidase activity. Then, cells were treated with $0.1 \%$ Triton X-100 (Sigma) at $4^{\circ} \mathrm{C}$ for 5 minutes and incubated with TUNEL reaction mixture $(50 \mu \mathrm{L})$ in a humidified chamber at $37^{\circ} \mathrm{C}$ for 1 hour. After washing in PBS, cells were incubated with $50 \mu \mathrm{L}$ converter-POD in a humidified chamber at $37^{\circ} \mathrm{C}$ for 1 hour. Samples were washed in PBS and exposed to the DAB (3,3-diaminobenzidine tetrahydrochloride) substrate solution for color development in a dark chamber at room temperature for 10 minutes. At last, samples were dehydrated in ethanol, cleared in xylene, and mounted with entelan. For each sample, at last 1000 nuclei were counted and data represented the mean values from three independent experiments. For negative controls, instead of the TUNEL reaction mixture, slides were incubated with $50 \mu \mathrm{L}$ of label solution (without terminal transferase). 


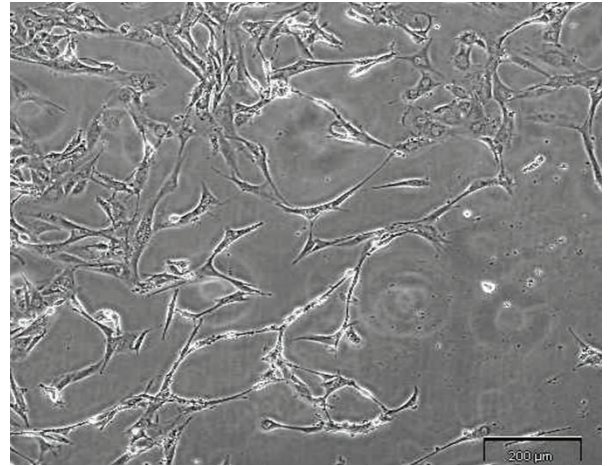

(a)

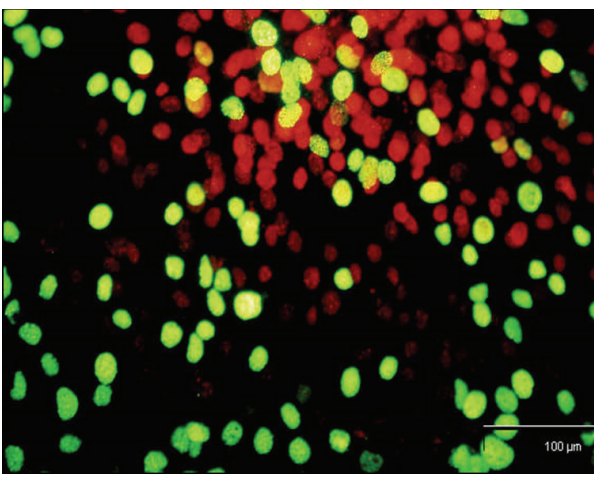

(c)

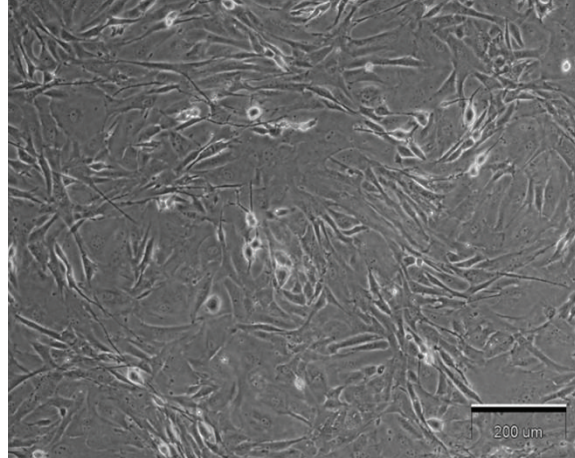

(b)

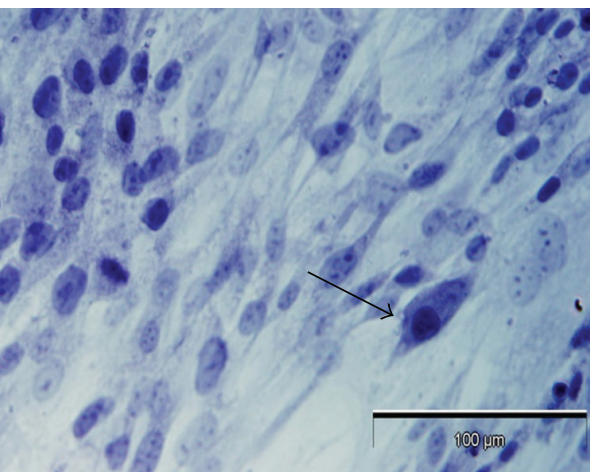

(d)

Figure 1: (a) Normally growing and (b) confluent sheep granulosa cells. The scale bars are $200 \mu \mathrm{m}$. (c) DNA synthesis of sheep granulosa cells as assayed by BrdU incorporation. Cells were normally growing. The scale bar is $100 \mu \mathrm{m}$. (d) TUNEL assay of sheep granulosa cells grown with 72-hour serum starvation. Arrows indicate TUNEL positive cells (apoptotic cells) that stained very dark. The scale bar is $100 \mu \mathrm{m}$.
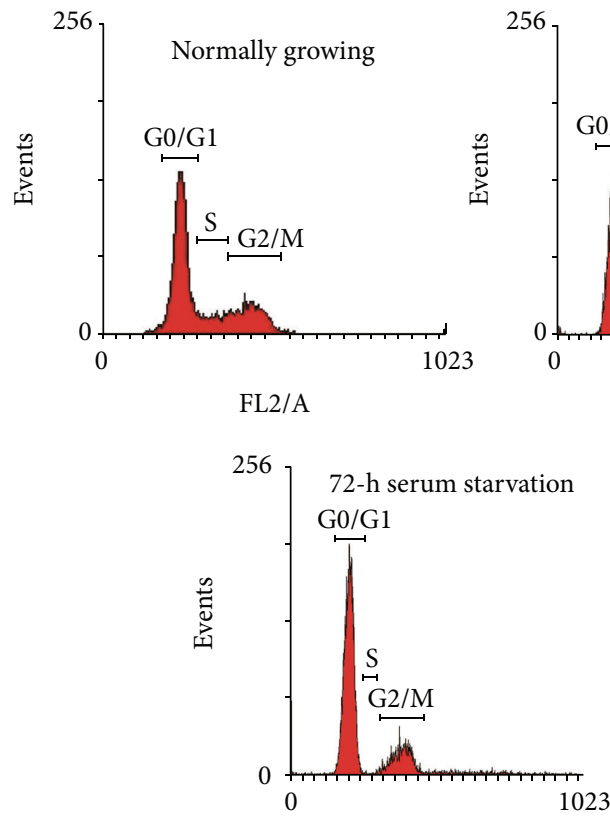

FL2/A

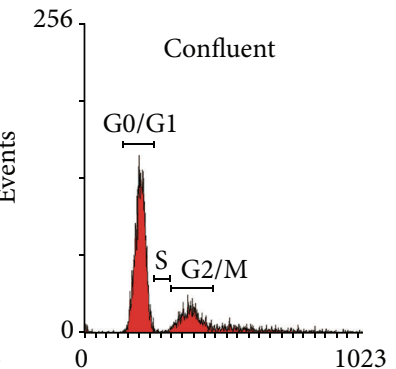

FL2/A

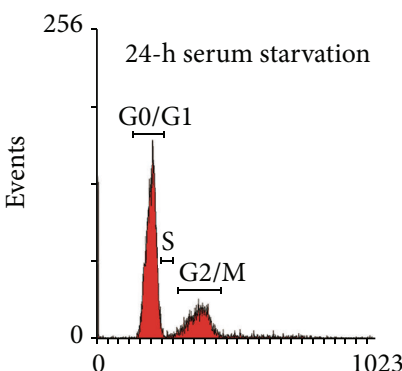

FL2/A

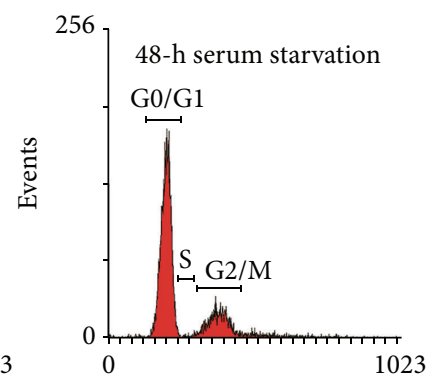

FL2/A

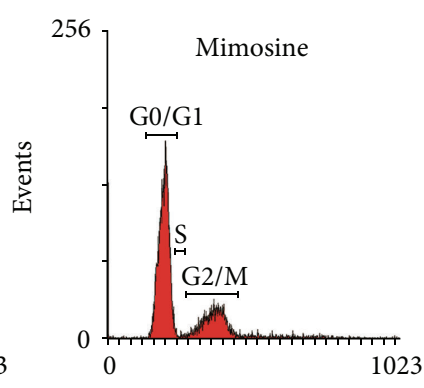

FL2/A

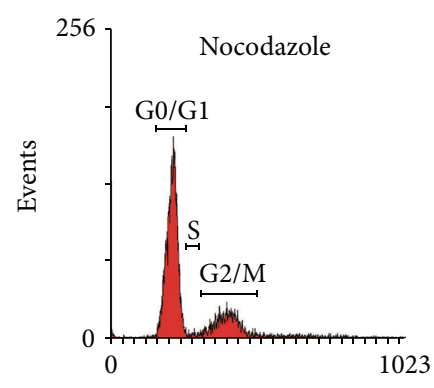

FL2/A

FIGURE 2: Typical histogram of DNA. Single-parameter histogram of DNA allows for the discrimination of cell populations existing in G0/G1; S; G2/M phases of the cell cycle. 
TABLE 1: Percentages $( \pm S D)$ of granulosa cells in various phases of the cell cycle after a variety of culture treatments in primary culture (a) and 5th passage (b).

(a)

\begin{tabular}{lccc}
\hline Treatment & G0/G1 & S & G2/M \\
\hline Normally growing & $56.4 \pm 2.7^{\mathrm{a}}$ & $19.0 \pm 0.5^{\mathrm{a}}$ & $23.3 \pm 2.5^{\mathrm{f}}$ \\
Confluency & $73.11 \pm 3.0^{\mathrm{bc}}$ & $8.81 \pm 1.41^{\mathrm{bc}}$ & $18.08 \pm 0.58^{\mathrm{a}}$ \\
24h SS & $76.9 \pm 1.6^{\mathrm{bc}}$ & $7.8 \pm 0.3^{\mathrm{bc}}$ & $15.3 \pm 0.9^{\mathrm{a}}$ \\
48 h SS & $83.5 \pm 1.3^{\mathrm{bd}}$ & $2.4 \pm 0.1^{\mathrm{bd}}$ & $14.1 \pm 0.6^{\mathrm{bc}}$ \\
$72 \mathrm{~h} \mathrm{SS}$ & $89.46 \pm 2.0^{\mathrm{bd}}$ & $1.9 \pm 0.3^{\mathrm{bd}}$ & $8.64 \pm 1.14^{\mathrm{bd}}$ \\
Mimosine & $85.2 \pm 1.1^{\mathrm{bd}}$ & $3.5 \pm 0.3^{\mathrm{bd}}$ & $11.3 \pm 0.6^{\mathrm{be}}$ \\
Nocodazole & $74.09 \pm 1.07^{\mathrm{bd}}$ & $2.7 \pm 0.5^{\mathrm{bd}}$ & $23.2 \pm 1.7^{\mathrm{abf}}$ \\
\hline
\end{tabular}

(b)

\begin{tabular}{lccc}
\hline Treatment & G0/G1 & S & G2/M \\
\hline Normally growing & $56.1 \pm 1.0^{\mathrm{a}}$ & $18.0 \pm 0.2^{\mathrm{a}}$ & $24.8 \pm 1.5^{\mathrm{a}}$ \\
Confluency & $72.6 \pm 1.0^{\mathrm{bc}}$ & $6.5 \pm 0.4^{\mathrm{bd}}$ & $20.9 \pm 1.4^{\mathrm{a}}$ \\
24 h SS & $75.4 \pm 2.2^{\mathrm{bc}}$ & $4.9 \pm 0.4^{\mathrm{bd}}$ & $19.7 \pm 0.5^{\mathrm{a}}$ \\
$48 \mathrm{~h} \mathrm{SS}$ & $85.7 \pm 2.3^{\mathrm{bd}}$ & $2.1 \pm 0.2^{\mathrm{bc}}$ & $12.2 \pm 0.6^{\mathrm{b}}$ \\
$72 \mathrm{~h} \mathrm{SS}$ & $90.7 \pm 1.72^{\mathrm{bd}}$ & $1.8 \pm 0.45^{\mathrm{bc}}$ & $7.32 \pm 0.42^{\mathrm{b}}$ \\
Mimosine & $85.5 \pm 1.3^{\mathrm{bd}}$ & $4.5 \pm 0.15^{\mathrm{bd}}$ & $10.0 \pm 0.5^{\mathrm{b}}$ \\
Nocodazole & $74.6 \pm 2.3^{\mathrm{b}}$ & $1.9 \pm 0.56^{\mathrm{bc}}$ & $23.5 \pm 1.8^{\mathrm{a}}$ \\
\hline
\end{tabular}

SS: Serum starvation. Data are means \pm SD. Values within the columns with different superscripts (a with $b$; $c$ with d; e with $\mathrm{f}$ ) differ significantly $(P<0.05)$.

2.6. Statistical Analysis. At first, the Kolmogrov-Smirnov test was performed for data normalization. The percentage of cells in each stage of the cell cycle for the experimental groups is given as the mean value of replicates \pm standard deviation (SD). Data were analyzed using ANOVA. DNA synthesis and apoptosis data and differences between treatments were determined using the $\chi^{2}$ test. The analyses were performed with SPSS 9.0 software (SPSS Inc., Chicago, IL, USA) and $P<0.05$ was considered significant.

\section{Results}

To evaluate the effect of confluency, serum starvation, and chemical cell cycle inhibitor on the cell cycle, DNA content was measured by FACS analysis, and the relative percentages of the proportions of cells in the G0/G1 (2C DNA content), S (2C-4C) and G2/M (4C DNA content) stages were calculated (Table 1).

The percentage of normally growing cells in the G0/G1 phase was $56.4 \%$ for primary culture and $56.1 \%$ for the 5 th passage, respectively. Confluent cells significantly increased the proportion of cells in the G0/G1 stage $(P<0.05)$ compared with normally growing cells $(73 / 11 \pm 3.0$ in primary culture and $72.6 \pm 1.0$ in the 5 th passage, resp.). After 24 , 48 and 72 hours of serum starvation, the relative percentage of cells that entered into G0/G1 significantly increased when compared with normally growing cells $(76.9 \pm 1.6,83.5 \pm 1.3$, $89.46 \pm 2.0$ in the primary culture and $75.4 \pm 2.2,85.7 \pm 2.3$, $90.7 \pm 1.72$ in the 5 th passage, resp.; $P<0.05)$. These results showed that the percentage of G0/G1 cells increased further by prolonging serum starvation to 72 hours when compared with normally growing cells. The percentage of cells in the $\mathrm{S}$ and $\mathrm{G} 2 / \mathrm{M}$ stages reduced with confluency and serum starvation cells $(P<0.05)$. Moreover, mimosine effectively arrested the cell cycle at the G0/G1 phase to $85.2 \pm 1.1(P<$ $0.05)$. Nocodazole treatment increased the number of cells in the $\mathrm{G} 0 / \mathrm{G} 1$ to $74.09 \pm 1.07$ in primary culture and $74.6 \pm 2.3$ in the 5 th passage (Figure 2). The number of cells in the G2/M stage was the same as the number of cells in the control group.

DNA synthesis showed that in primary culture and the 5th passage, 19.8 and $18 \%$ of normally growing cells were in the $S$ phase, respectively. The percentage of cells in the $S$ phase changed significantly with confluency and 24-hour serum deprivation cells $(10.2 \%$ in primary culture and $9.6 \%$ in the 5th passage, resp.; $P<0.05)$. When cells were starved for 48 and 72 hours, the percentage of BrdU labeled cells significantly decreased to 3.1 and $2.2 \%$ in primary culture and 3.2 and $2.3 \%$ in the 5 th passage, respectively $(P<0.05)$. Cells treated with mimosine and nocodazole also resulted in a decrease in DNA synthesis in cell cultures (Table 2, Figure 1(c)).

Detection by TUNEL (Figure $1(\mathrm{~d})$ ) revealed a few apoptosis $(2.62 \%)$ in normally growing cells. Apoptosis in confluent cells did not increase significantly when compared with the control group. Serum starvation promoted cell apoptosis and the degree of apoptosis was correlated with the length of starvation. When cells were starved for 24 hours, the percentage of apoptotic cells did not increase significantly. However when they were starved for 48 or 72 hours, the percentages of apoptotic cells (5.6 and 6.1 in primary; 5.4 and $6.5 \%$ in the 5 th passage, resp.) increased $(P<0.05)$. Treatment of cells with nocodazole and mimosine did not increase the percentage of apoptotic cells (Table 3 ).

\section{Discussion}

There are different factors that affect in vitro as well as in vivo development of reconstructed embryos following NT. Cell cycle synchronization between nuclear donor and the recipient is considered to be one of the crucial factors for successful cloning.

Data from this study clearly indicate that sheep granulosa cells could be synchronized effectively at the G0/G1 stages using all six different treatments. The majority of the cells $(>70 \%)$ in all groups were arrested at the G0/G1 stage, while in normally growing granulosa $56 \%$ of the cells were allocated to this stage. Urakawa et al. (2004) showed that a high rate of offspring production was possible by NT using donor cells that were in the early G1 phase [28]. Hayes et al. [29] determined that hyperconfluency alone was sufficient to induce bovine fibroblasts and granulosa cells to enter G0 and there was no difference in the rate of blastocyst development with culture in vitro, when compared to serum starved cells. Recently, Dalman et al. (2010) have shown that full confluency is an effective method for cell cycle synchronization [30]. Khammanit et al. and de Barros et al. have reported that serum starvation and growth to confluency successfully synchronized fibroblast cells at the 
TABLE 2: Percentages of granulosa cells in S phase of the cell cycle after a variety of culture treatments in primary culture (a) and 5th passage (b).

(a)

\begin{tabular}{ccccccc}
\hline & \multirow{2}{*}{ Normally growing } & \multirow{2}{*}{ Confluency } & \multicolumn{3}{c}{ Serum starvation } & \multicolumn{2}{c}{ Cell cycle inhibitors } \\
& & $24 \mathrm{~h}$ & $48 \mathrm{~h}$ & $72 \mathrm{~h}$ & Mimosine & Nocodazole \\
\hline S stage & $19.8 \%^{\mathrm{a}}$ & $10.2 \%^{\mathrm{b}}$ & $8.5 \%^{\mathrm{b}}$ & $3.1 \%^{\mathrm{b}}$ & $2.2 \%^{\mathrm{b}}$ & $4.5 \%^{\mathrm{b}}$ \\
\hline
\end{tabular}

(b)

\begin{tabular}{ccccccc}
\hline & Normally growing & \multirow{2}{*}{ Confluency } & \multicolumn{3}{c}{ Serum starvation } & \multicolumn{2}{c}{ Cell cycle inhibitors } \\
& & $24 \mathrm{~h}$ & $48 \mathrm{~h}$ & $72 \mathrm{~h}$ & Mimosine & Nocodazole \\
\hline S stage & $18 \%^{\mathrm{a}}$ & $9.6 \%^{\mathrm{b}}$ & $5.5 \%^{\mathrm{b}}$ & $3.2 \%^{\mathrm{b}}$ & $2.3 \%^{\mathrm{b}}$ & $3.1 \%^{\mathrm{b}}$ \\
\hline
\end{tabular}

Within a row; percentages with different superscript alphabets are significant $(P<0.05)$.

TABLE 3: Apoptosis of sheep granulosa cells after various treatments by TUNEL assay in primary culture (a) and 5th passage (b).

(a)

\begin{tabular}{|c|c|c|c|c|c|c|c|}
\hline & \multirow{2}{*}{ Normally growing } & \multirow{2}{*}{ Confluency } & \multicolumn{3}{|c|}{ Serum starvation } & \multicolumn{2}{|c|}{ Cell cycle inhibitors } \\
\hline & & & $24 \mathrm{~h}$ & $48 \mathrm{~h}$ & $72 \mathrm{~h}$ & Mimosine & Nocodazole \\
\hline Viable cells & $97.3 \%^{\mathrm{a}}$ & $95.2 \%$ & $94.8 \%^{\mathrm{a}}$ & $94.3 \%$ & $93.7 \%^{\mathrm{b}}$ & $95.1 \%$ & $95 \%$ \\
\hline Apoptotic cells & $2.62 \%^{\mathrm{a}}$ & $4.7 \%$ & $5.1 \%$ & $5.6 \%^{\mathrm{b}}$ & $6.1 \%^{\mathrm{b}}$ & $4.8 \%$ & $4.9 \%$ \\
\hline
\end{tabular}

(b)

\begin{tabular}{|c|c|c|c|c|c|c|c|}
\hline & \multirow{2}{*}{ Normally growing } & \multirow{2}{*}{ Confluency } & \multicolumn{3}{|c|}{ Serum starvation } & \multicolumn{2}{|c|}{ Cell cycle inhibitors } \\
\hline & & & $24 \mathrm{~h}$ & $48 \mathrm{~h}$ & $72 \mathrm{~h}$ & Mimosine & Nocodazole \\
\hline Viable cells & $97 \%$ & $95.1 \%$ & $94.7 \%$ & $94.5 \%^{\mathrm{b}}$ & $93.3 \%^{\mathrm{b}}$ & $94.8 \%$ & $95 \%$ \\
\hline Apoptotic cells & $2.9 \%^{\mathrm{a}}$ & $4.8 \%$ & $5.2 \%$ & $5.4 \%^{\mathrm{b}}$ & $6.5 \%^{\mathrm{b}}$ & $5.1 \%$ & $4.9 \%$ \\
\hline
\end{tabular}

Within a row; percentages with different superscript alphabets are significant $(P<0.05)$. The percentages without superscript alphabets are not significant.

G0/G1 stage [31, 32]. Kasinathan et al. compared two methods of high confluency and the shake-off method for bovine fibroblast cells [19]. They found that high confluency was more effective than serum starvation in arresting the cell cycle. They demonstrated that G1 cells support a higher development rate of NT embryos to term than cells obtained from a full confluent culture. Interestingly, the effect was not observed until late gestation. Therefore, cell cycle progression in nuclear donor cells appears to be an advantage for the successful development of NT embryos through the final stages of gestation. It is possible that the inhibitory effect of high confluence on cell cycle progression may have negative effects on development of cloned embryo, especially through the final stages of gestation [19].

The importance of serum starvation of the donor cells was emphasized with the birth of Dolly [22]. In this study, serum starvation for 24 hours did not significantly decrease DNA synthesis. Analysis of cell cycle distribution by flow cytometry showed that serum starvation for 48 and 72 hours significantly increased G0/G1 phase cells in both primary culture and 5 th passage. However, extension of the serum deprivation period to greater than 48 hours reduced cell survival and increased DNA fragmentation with some characteristics of apoptosis $[2,24]$.

In the present study, confluent cells and serum starvation for 24 and 48 hours did not increase apoptotic cells, but serum starvation for 72 hours significantly promoted apoptosis in sheep granulosa cells. Jayadev et al. showed that serum starvation increased the number of apoptotic cells (12\%), while inhibiting the cell cycle progress in leukemia cells [33]. Growing goat fibroblasts cultured in vitro had low rate of apoptosis (1.15\%), but when the cells were serum starved for five days, the percentage of apoptotic cells reached $11.7 \%$ and after 10 days of starvation, and most cells showed signs of apoptosis [34]. Dalman et al. also showed that 72hour serum starvation induced $39.83 \%$ early apoptosis and $1.95 \%$ late apoptosis in goat fibroblast cells [30]. High rates of fetal loss in cattle clones related to serum starvation of donor cells have been documented by Gibbons et al. (2002). These authors assumed that long-term fetal losses of clones derived from serum starved donor cells may be consistent with inappropriate DNA replication or DNA damage [27]. Exposing donor cells to chemical inhibitors is an alternative method for synchronizing cells at the G0/G1 phase. In this study, we investigated the effect of mimosine and nocodazole. The synchronization effect of mimosine has been proven by Krude (1999), who confirmed that treatment of asynchronously proliferating human somatic HeLa or EJ30 cells with $0.5 \mathrm{mM}$ mimosine for sufficient time to undergo at least one full cell division cycle resulted in a homogenous population of cells synchronized in the late G1 phase [35].

It has been reported that mimosine added to cultures of a variety of cell lines at $0.2 \mathrm{mM}$ reversibly arrests cells late in the G1 phase [36] by reducing the activity of the protein synthesis 
initiation factor eIF-5A [37]. In contrast, Boquest et al. have shown that mimosine treatment had little effect on increasing G1 percentages of fetal fibroblasts, even when added at a high concentration of $1.2 \mathrm{mM}$ [38]. Once again, this result highlights the importance of verifying the responsiveness of each cell line to a particular cell cycle-arresting treatment. It has been shown by flow cytometry of cultured human lymphoid cells that mimosine inhibits cell cycle traverse in the late G1 phase near the G1-to-S transition [36]. Prather et al. observed that mimosine treatment of mammary cells resulted in synchronization in the G1 phase in comparison with cycling culture [25]; while serum deprivation for five days resulted in $22 \%$ of the cells in G0 and $63.8 \%$ of the cells in G1. Our results were similar to those of Vacková et al. (2003) who demonstrated that 24 hours of treatment with $0.5 \mathrm{mM}$ mimosine caused effective arrest of the cell cycle in the G1 phase [14]. The potential of cells to divide was preserved even after 24 hours of mimosine inhibition. Also, we showed that mimosine treatment did not increase the number of apoptotic cells.

This study showed that nocodazole treatment increased the number of cells in the G0/G1 stage but did not change the cell numbers in the G2/M stage. It has been hypothesized that $\mathrm{M}$ phase somatic donor cells introduced to MII oocytes would be tetraploid if treated with a protein or phosphorylation inhibitor, such as 6-DMAP, due to detrimental effects on spindle function [39]. A previous study by Cheong et al. has shown an increased number of tetraploid embryos (23\%) derived from G2 donor cells compared to G1 donor cells $(0 \%)$ [15]. Transfer of $\mathrm{M}$ phase nuclei to both activated and nonactivated MII cytoplasts was not as successful at supporting development to the blastocyst stage as G0 and G1 nuclei [39]. Nocodazole arrests cells at metaphase by inhibiting tubulin polymerization [40]. A previous study has reported that although nocodazole inhibits cells to produce a cell population with a G2-phase amount of DNA, these cells are not synchronized. Not only is the cell-size distribution of inhibited cells not narrowed as expected for a truly synchronized culture, but also, upon release of cells from nocodazole, the cells do not progress normally through the cell cycle. Thus, nocodazole has a deleterious or damaging effect on cells [41]. Cooper et al. indicated that nocodazole can be used to synchronize nuclear donor cells at the G1 or S phases after exiting from M-phase, and fusions can be affected between 2 and 4 hours (G1) and 6-8 hours (S phase) after removal of the agent [42].

\section{Conclusions}

In conclusion, the results of the primary culture and 5th passage showed confluency, serum starvation. and mimosine treatments effectively synchronized sheep granulosa cells in the G0/G1 phase. As a result, using nocodazol treatment for cell cycle synchronization is not suitable in the NT process. We recommend the use of confluency, 48-hour serum starvation and mimosine, because cell death in these groups was very similar to the control group (normally growing). However serum starvation for 72 hours significantly promoted apoptosis in granulosa cells. Our results should be of value in preparing sheep donor cells for NT experiments.

\section{Conflict of Interests}

The authors declare that there is no conflict of interests regarding the publication of this paper.

\section{Acknowledgments}

The authors thank F. Shabani for statistical analysis. They thank S. Soudi for technical assistance. This study was financially supported by the Royan Institute.

\section{References}

[1] C. Galli, I. Lagutina, G. Crotti et al., "A cloned horse born to its dam twin," Nature, vol. 424, no. 6949, p. 635, 2003.

[2] J. B. Cibelli, S. L. Stice, P. J. Golueke et al., "Cloned transgenic calves produced from nonquiescent fetal fibroblasts," Science, vol. 280, no. 5367, pp. 1256-1258, 1998.

[3] T. Wakayama, A. C. F. Perry, M. Zuccotti, K. R. Johnson, and R. Yanagimachi, "Full-term development of mice from enucleated oocytes injected with cumulus cell nuclei," Nature, vol. 394, no. 6691, pp. 369-374, 1998.

[4] A. Baguisi, E. Behboodi, D. T. Melican et al., "Production of goats by somatic cell nuclear transfer," Nature Biotechnology, vol. 17 , no. 5, pp. 456-461, 1999.

[5] A. Onishi, M. Iwamoto, T. Akita et al., "Pig cloning by microinjection of fetal fibroblast nuclei," Science, vol. 289, no. 5482, pp. 1188-1190, 2000.

[6] T. Shin, D. Kraemer, J. Pryor et al., "A cat cloned by nuclear transplantation," Nature, vol. 415, no. 6874, p. 859, 2002.

[7] H.-T. Cheong, Y. Takahashi, and H. Kanagawa, "Birth of mice after transplantation of early cell-cycle-stage embryonic nuclei into enucleated oocytes," Biology of Reproduction, vol. 48, no. 5, pp. 958-963, 1993.

[8] Y. Kato, T. Tani, Y. Sotomaru et al., "Eight calves cloned from somatic cells of a single adult," Science, vol. 282, no. 5396, pp. 2095-2098, 1998.

[9] I. A. Polejaeva, S.-H. Chen, T. D. Vaught et al., "Cloned pigs produced by nuclear transfer from adult somatic cells," Nature, vol. 407, no. 6800, pp. 86-90, 2000.

[10] A. E. Schníeke, A. J. Kind, W. A. Ritchie et al., "Human factor IX transgenic sheep produced by transfer of nuclei from transfected fetal fibroblasts," Science, vol. 278, no. 5346, pp. 2130-2133, 1997.

[11] K. J. McCreath, J. Howcroft, K. H. S. Campbell, A. Colman, A. E. Schnieke, and A. J. Kind, "Production of gene-targeted sheep by nuclear transfer from cultured somatic cells," Nature, vol. 405, pp. 1066-1069, 2000.

[12] Y. Heyman, P. Chavatte-Palmer, D. LeBourhis, S. Camous, X. Vignon, and J. P. Renard, "Frequency and occurrence of late-gestation losses from cattle cloned embryos," Biology of Reproduction, vol. 66, no. 1, pp. 6-13, 2002.

[13] J. R. Hill, R. C. Burghardt, K. Jones et al., "Evidence for placental abnormality as the major cause of mortality in first-trimester somatic cell cloned bovine fetuses," Biology of Reproduction, vol. 63, no. 6, pp. 1787-1794, 2000. 
[14] I. Vacková, M. Engelová, I. Marinov, and M. Tománek, "Cell cycle synchronization of porcine granulosa cells in G1 stage with mimosine," Animal Reproduction Science, vol. 77, no. 3-4, pp. 235-245, 2003.

[15] H.-T. Cheong, Y. Takahashi, and H. Kanagawa, "Birth of mice after transplantation of early cell-cycle-stage embryonic nuclei into enucleated oocytes," Biology of Reproduction, vol. 48, no. 5, pp. 958-963, 1993.

[16] P. Collas, C. Pinto-Correia, F. A. Ponce De Leon, and J. M. Robl, "Effect of donor cell cycle stage on chromatin and spindle morphology in nuclear transplant rabbit embryos," Biology of Reproduction, vol. 46, no. 3, pp. 501-511, 1992.

[17] K. H. S. Campbell, J. McWhir, W. A. Ritchie, and I. Wilmut, "Sheep cloned by nuclear transfer from a cultured cell line," Nature, vol. 380, no. 6569, pp. 64-66, 1996.

[18] I. A. Polejaeva, S.-H. Chen, T. D. Vaught et al., "Cloned pigs produced by nuclear transfer from adult somatic cells," Nature, vol. 407, no. 6800, pp. 86-90, 2000.

[19] P. Kasinathan, J. G. Knott, Z. Wang, D. J. Jerry, and J. M. Robl, "Production of calves from G1 fibroblasts," Nature Biotechnology, vol. 19, no. 12, pp. 1176-1178, 2001.

[20] X. Zou, Y. Wang, Y. Cheng et al., "Generation of cloned goats (Capra hircus) from transfected foetal fibroblast cells, the effect of donor cell cycle," Molecular Reproduction and Development, vol. 61, no. 2, pp. 164-172, 2002.

[21] D. N. Wells, P. M. Misica, and H. R. Tervit, "Production of cloned calves following nuclear transfer with cultured adult mural granulosa cells," Biology of Reproduction, vol. 60, no. 4, pp. 996-1005, 1999.

[22] I. Wilmut, A. E. Schnieke, J. McWhir, A. J. Kind, and K. H. S. Campbell, "Viable offspring derived from fetal and adult mammalian cells," Nature, vol. 385, no. 6619, pp. 810-813, 1997.

[23] B. P. Enright, B. S. Jeong, X. Yang, and X. C. Tian, "Epigenetic characteristics of bovine donor cells for nuclear transfer: levels of histone acetylation," Biology of Reproduction, vol. 69, no. 5, pp. 1525-1530, 2003.

[24] W. A. Kues, M. Anger, J. W. Carnwath, D. Paul, J. Motlik, and H. Niemann, "Cell cycle synchronization of porcine fetal fibroblasts: effects of serum deprivation and reversible cell cycle inhibitors," Biology of Reproduction, vol. 62, no. 2, pp. 412-419, 2000.

[25] R. S. Prather, A. C. Boquest, and B. N. Day, "Cell cycle analysis of cultured porcine mammary cells," Cloning and Stem Cells, vol. 1, no. 1, pp. 17-24, 1999.

[26] M. S. Mohamed Nour, K. Ikeda, and Y. Takahashi, "Bovine nuclear transfer using cumulus cells derived from serumstarved and confluent cultures," Journal of Reproduction and Development, vol. 46, no. 2, pp. 85-92, 2000.

[27] J. Gibbons, S. Arat, J. Rzucidlo et al., "Enhanced survivability of cloned calves derived from roscovitine-treated adult somatic cells," Biology of Reproduction, vol. 66, no. 4, pp. 895-900, 2002.

[28] M. Urakawa, A. Ideta, T. Sawada, and Y. Aoyagi, "Examination of a modified cell cycle synchronization method and bovine nuclear transfer using synchronized early G1 phase fibroblast cells," Theriogenology, vol. 62, no. 3-4, pp. 714-728, 2004.

[29] O. Hayes, B. Ramos, L. L. Rodríguez, A. Aguilar, T. Badía, and F. O. Castro, "Cell confluency is as efficient as serum starvation for inducing arrest in the G0/G1 phase of the cell cycle in granulosa and fibroblast cells of cattle," Animal Reproduction Science, vol. 87, no. 3-4, pp. 181-192, 2005.
[30] A. Dalman, P. Eftekhari-Yazdi, M. R. Valojerdi et al., "Synchronizing cell cycle of goat fibroblasts by serum starvation causes apoptosis," Reproduction in Domestic Animals, vol. 45, no. 5, pp. e46-e53, 2010

[31] R. Khammanit, S. Chantakru, Y. Kitiyanant, and J. Saikhun, "Effect of serum starvation and chemical inhibitors on cell cycle synchronization of canine dermal fibroblasts," Theriogenology, vol. 70, no. 1, pp. 27-34, 2008.

[32] F. R. O. de Barros, M. D. Goissis, H. V. A. Caetano et al., "Serum starvation and full confluency for cell cycle synchronization of domestic cat (Felis catus) foetal fibroblasts," Reproduction in Domestic Animals, vol. 45, no. 1, pp. 38-41, 2010.

[33] S. Jayadev, B. Liu, A. E. Bielawska et al., "Role for ceramide in cell cycle arrest," Journal of Biological Chemistry, vol. 270, no. 5, pp. 2047-2052, 1995.

[34] Y. S. Yu, X. S. Sun, H. N. Jiang, Y. Han, C. B. Zhao, and J. H. Tan, "Studies of the cell cycle of in vitro cultured skin fibroblasts in goats: work in progress," Theriogenology, vol. 59, no. 5-6, pp. 1277-1289, 2003.

[35] T. Krude, "Mimosine arrests proliferating human cells before onset of DNA replication in a dose-dependent manner," Experimental Cell Research, vol. 247, no. 1, pp. 148-159, 1999.

[36] M. Lalande, "A reversible arrest point in the late G1 phase of the mammalian cell cycle," Experimental Cell Research, vol. 186, no. 2, pp. 332-339, 1990.

[37] R. T. Johnson, C. S. Downes, and R. E. Meyn, The Synchronization of Mammalian Cells, Oxford University Press, New York, NY, USA, 1993.

[38] A. C. Boquest, B. N. Day, and R. S. Prather, "Flow cytometric cell cycle analysis of cultured porcine fetal fibroblast cells," Biology of Reproduction, vol. 60, no. 4, pp. 1013-1019, 1999.

[39] N. Korfiatis, A. Trounson, and O. Lacham-Kaplan, "Cell synchronization for the purposes of nuclear transfer in the bovine," Cloning and Stem Cells, vol. 3, no. 3, pp. 125-138, 2001.

[40] P. J. Otaegui, G. T. O’Neill, K. H. S. Campbell, and I. Wilmut, "Transfer of nuclei from 8-cell stage mouse embryos following use of nocodazole to control the cell cycle," Molecular Reproduction and Development, vol. 39, no. 2, pp. 147-152, 1994.

[41] S. Cooper, G. Iyer, M. Tarquini, and P. Bissett, "Nocodazole does not synchronize cells: implications for cell-cycle control and whole-culture synchronization," Cell and Tissue Research, vol. 324, no. 2, pp. 237-242, 2006.

[42] S. Cooper, G. Iyer, M. Tarquini, and P. Bissett, "Nocodazole does not synchronize cells, implications for cell-cycle control and whole-culture synchronization," Cell and Tissue Research, vol. 324, pp. 237-242, 2006. 

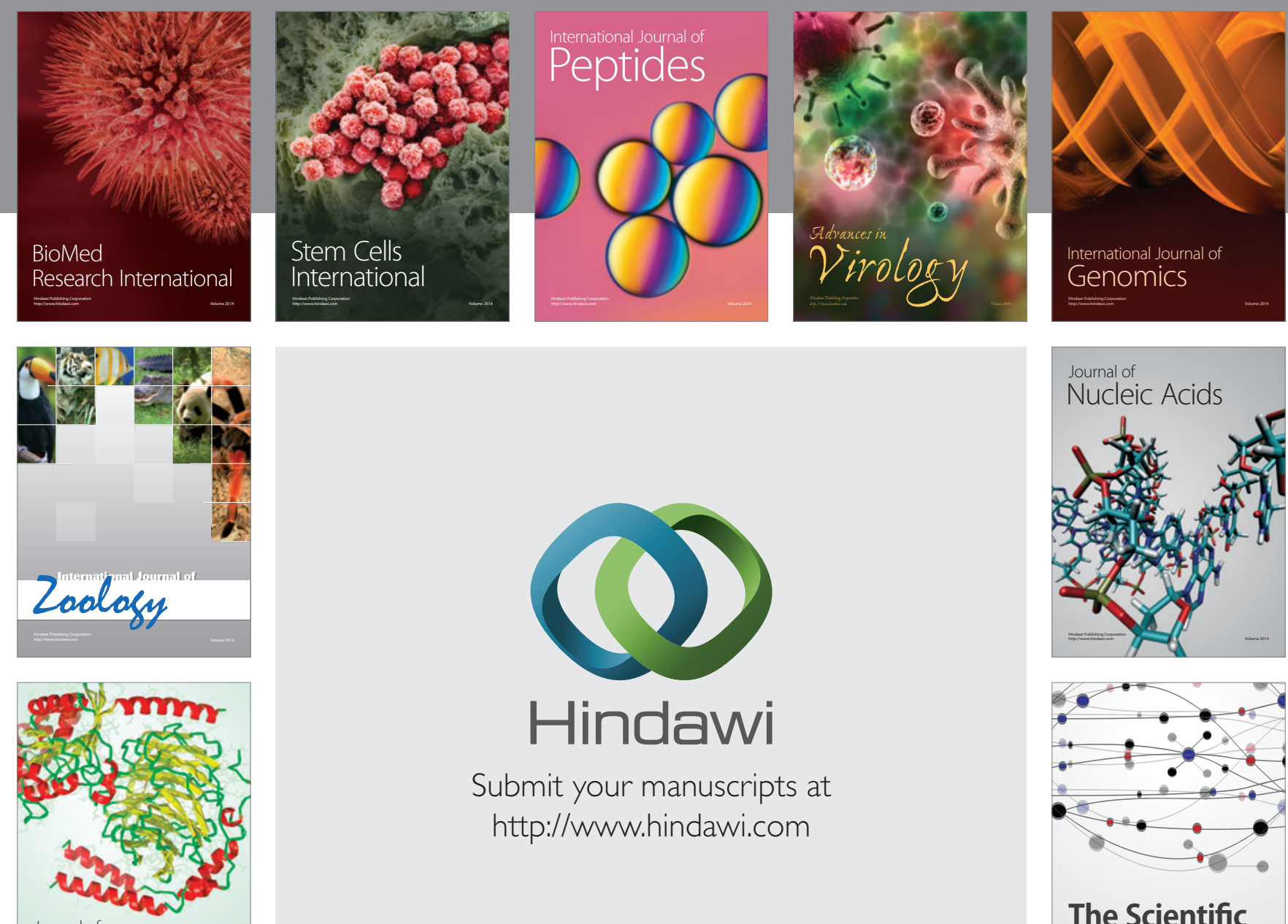

Submit your manuscripts at

http://www.hindawi.com

Journal of
Signal Transduction
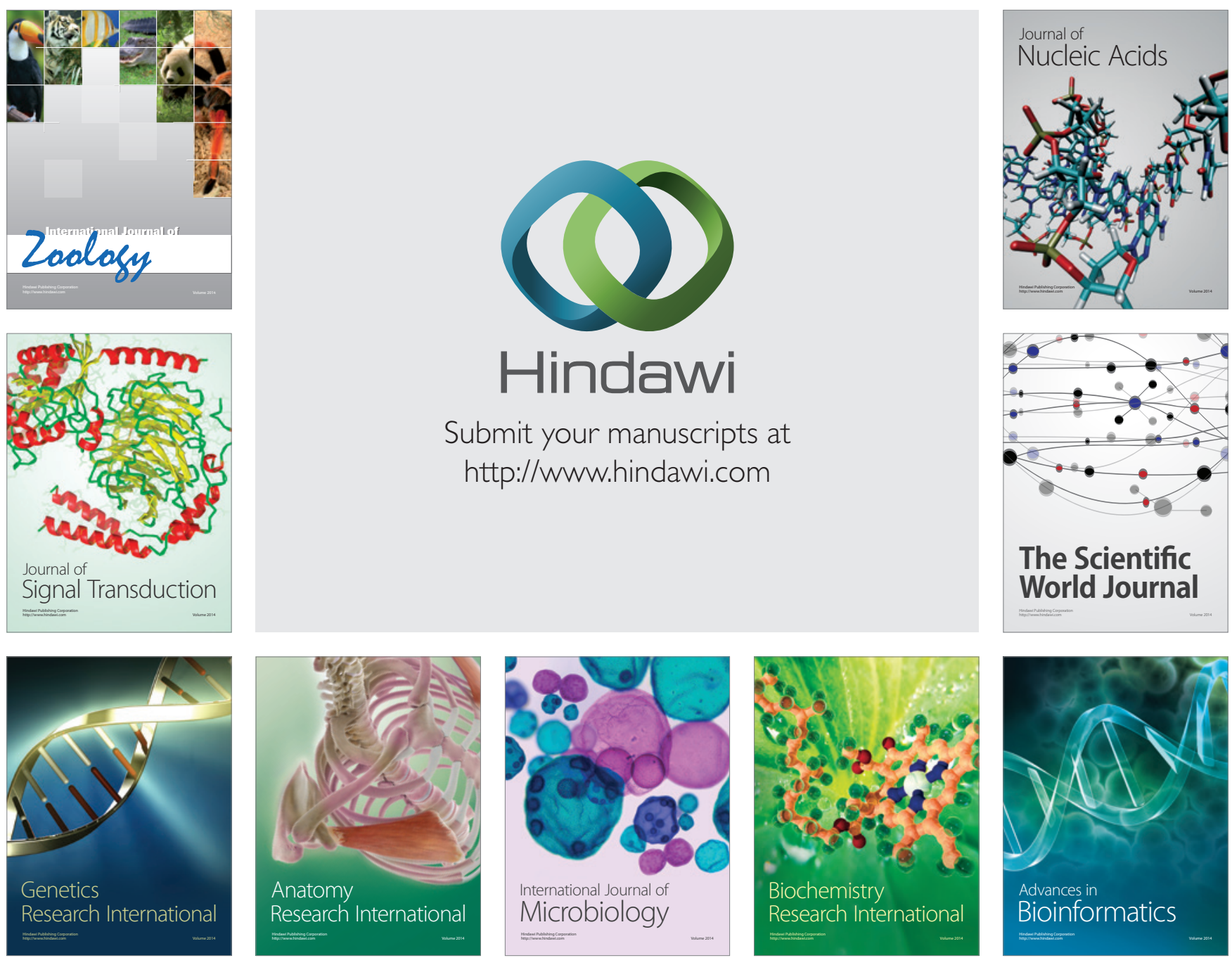

The Scientific World Journal
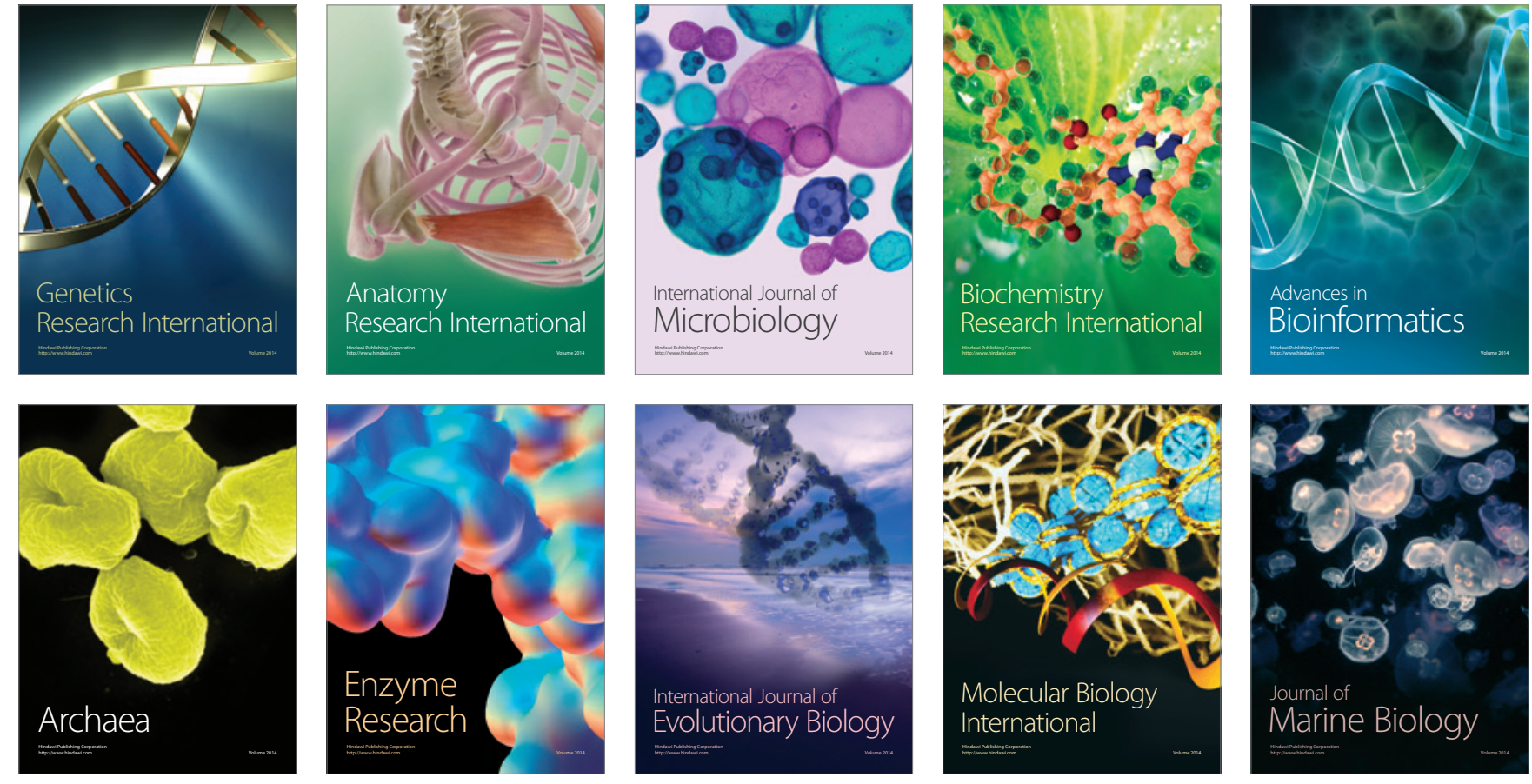